\title{
The Cosmonaut Sea Wedge
}

\author{
K. Solli, ${ }^{1}$ B. Kuvaas, ${ }^{1}$ Y. Kristoffersen,,${ }^{1}$ G. Leitchenkov, ${ }^{2}$ J. Guseva, ${ }^{3}$ V. Gandyukhin ${ }^{3}$ \\ ${ }^{1}$ Department of Earth Science, University of Bergen, N-5007 Bergen, Norway \\ ${ }^{2}$ VNIIOkeangeologia, 1, Angliysky Ave., 190121 St.Petersburg, Russia \\ ${ }^{3}$ PMGRE, 24, Pobedy Street, 189510 Lomonosov, Russia
}

Abstract A set of multi-channel seismic profiles ( 15000 km) acquired by Russia, Norway and Australia has been used to investigate the depositional evolution of the Cosmonaut Sea margin of East Antarctica. We recognize a regional sediment wedge below the upper part of the continental rise. The wedge, herein termed the Cosmonaut Sea Wedge, is positioned stratigraphically underneath the inferred glaciomarine section and extends for at least $1200 \mathrm{~km}$ along the continental margin and from 80 to about $250 \mathrm{~km}$ seaward or to the north. Lateral variations in the growth pattern of the wedge indicate several overlapping depocentres, which at their distal northern end are flanked by elongated mounded drifts and contourite sheets. The internal stratification of the mounded drift deposits suggests that westward flowing bottom currents reworked the marginal deposits. The action of these currents together with sea-level changes is considered to have controlled the growth of the wedge. We interpret the Cosmonaut Sea Wedge as a composite feature comprising several bottom current reworked fan systems.

Citation: Solli, K., B. Kuvaas, Y. Kristoffersen, G. Leitchenkov, J. Guseva and V. Gandyukhin (2007). The Cosmonaut Sea Wedge, in Antarctica: A Keystone in a Changing World - Online Proceedings of the $10^{\text {th }}$ ISAES, edited by A. K. Cooper and C. R. Raymond et al., USGS Open-File Report 2007-1047, Short Research Paper 009, 4 p.; doi:10.3133/of2007-1047.srp009.

\section{Introduction}

Several studies along the circum-Antarctic continental margin have demonstrated that the deposits underlying the continental slope and rise are products of both downslope gravitational processes and along-slope currents. The overall geometry of the depositional features is controlled by several interrelated factors such as: 1) the morphological context or bathymetric framework, 2) the velocity and variability of the bottom currents, 3) the amount and type of sediment available, 4) the length of time over which the bottom currents have operated, etc. The result is a variety of features (Faugeres et al., 1999; Stow et al., 2002), and one example is the regional sedimentary wedge recently reported from the Cosmonaut Sea (Figs. 1 and 2, Kuvaas et al., 2004; Kuvaas et al., 2005).

This sedimentary wedge is situated at the foot of the slope (Fig. 2) and appears to extend for at least $1200 \mathrm{~km}$ along the continental margin, with a maximum width of about $250 \mathrm{~km}$ seawards of Amundsen Bay (Fig. 1, Kuvaas et al., 2004; Kuvaas et al., 2005). The initial analysis of this sedimentary unit suggested that it might represent one of the largest drift deposits ever observed.

The purpose of this study is two-fold: (1) to analyse the multi-channel seismic data with a stratigraphic approach and reconstruct the main stages of the depositional history leading up to the formation of the regional wedge, (2) to further investigate the structure and morphology of the regional wedge itself with the aid of additional multi-channel seismic data recently made available through the Scientific Committee for Antarctic Research (SCAR) Seismic Data Library System (SDLS).

\section{Seismic database}

Nearly $15000 \mathrm{~km}$ of multi-channel seismic data has been analysed along this segment of the East Antarctic continental margin (Fig. 1). The main part of the database was acquired by the Polar Marine Geophysical Expedition (PMGE) of Russia in cooperation with the Norwegian Petroleum Directorate (NPD) of Norway. The database also contains a number of seismic dip-lines acquired on behalf of Geoscience Australia by Fugro Geoteam during the GA-228 survey. These 36 fold data are of very high quality and can be accessed through the SDLS.

\section{Seismic sequences}

The sedimentary section below the sea floor of the Cosmonaut Sea has been stratigraphically analysed on the basis of acoustic character and stratal geometry. The seismic sequences are termed (CS-A-CS-D), and the separating horizons are termed (CS-1-CS-4) (Fig. 3). The stratigraphic subdivision corresponds to that of Leitchenkov et al. (this volume), though not including the CS-3 surface as it does not mark a change in seismic reflection pattern in this sector of the Antarctic margin.

\section{CS-A}

The base of the lowermost sedimentary unit is marked by a distinct seismic reflector (AB). This surface appears as a high amplitude reflection that separates the irregular and nearly transparent pattern of reflections below from a well-defined package of dominantly continuous and parallel reflections above (Fig. 3).

Interpretation: The $(\mathrm{AB})$ surface is considered to indicate acoustic basement (bedrock) beneath the overlying sediment succession. The basement topography is for the most part draped by a well-stratified and laterally extensive sediment package (CS-A), suggesting a dominance of hemi-pelagic deposits. 


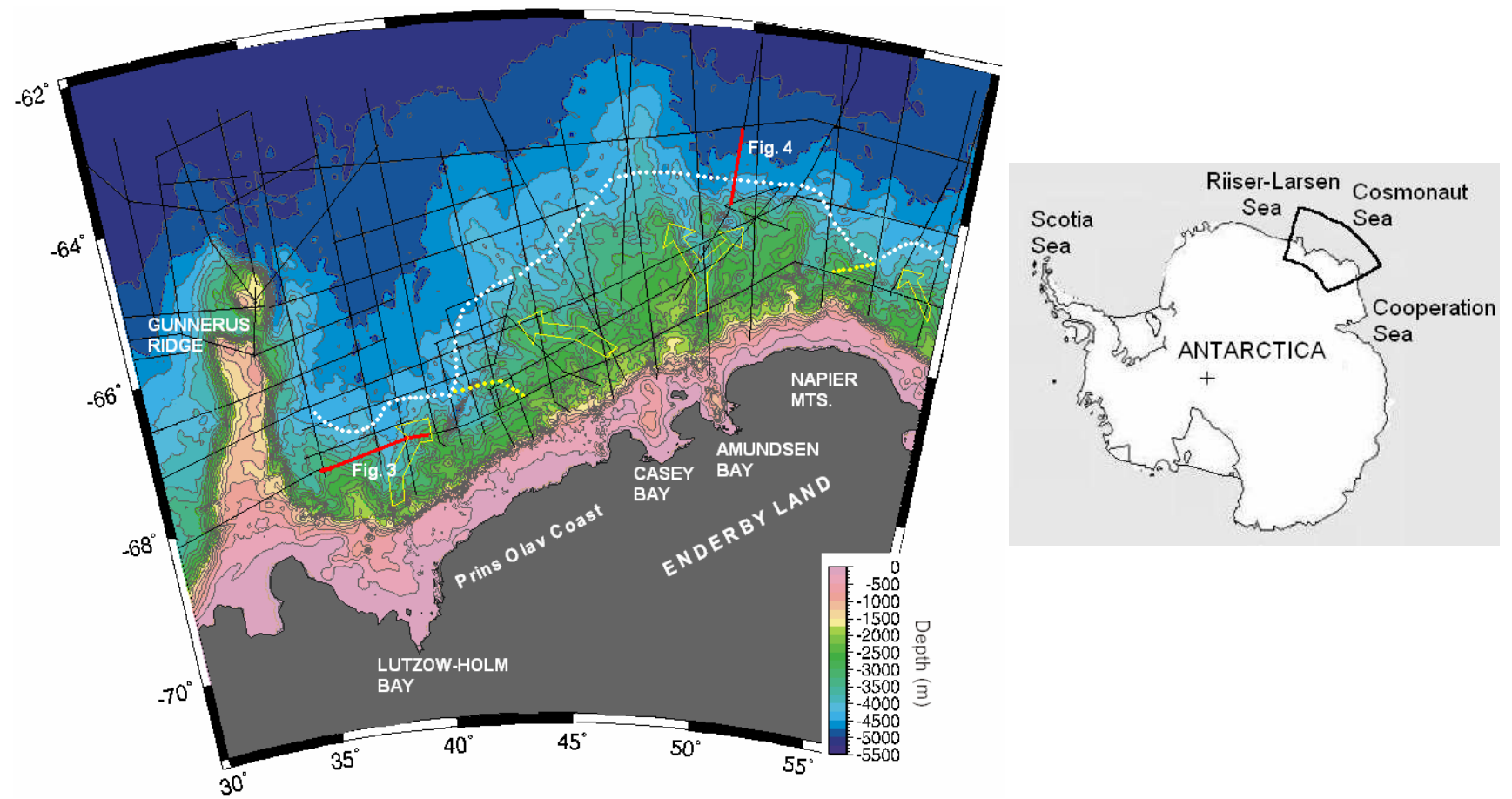

Figure 1: Map of Antarctica, showing the location of the study area (right). Bathymetric map of the Cosmonaut Sea (left), with location of seismic profiles (black lines). The distal margin of the regional wedge is marked with a dotted white line. The yellow dotted lines indicate respectively the eastern margin of the westernmost depocenter, and the western margin of the easternmost depocenter. Yellow arrows outline the main axis of progradation within different sectors of the wedge.

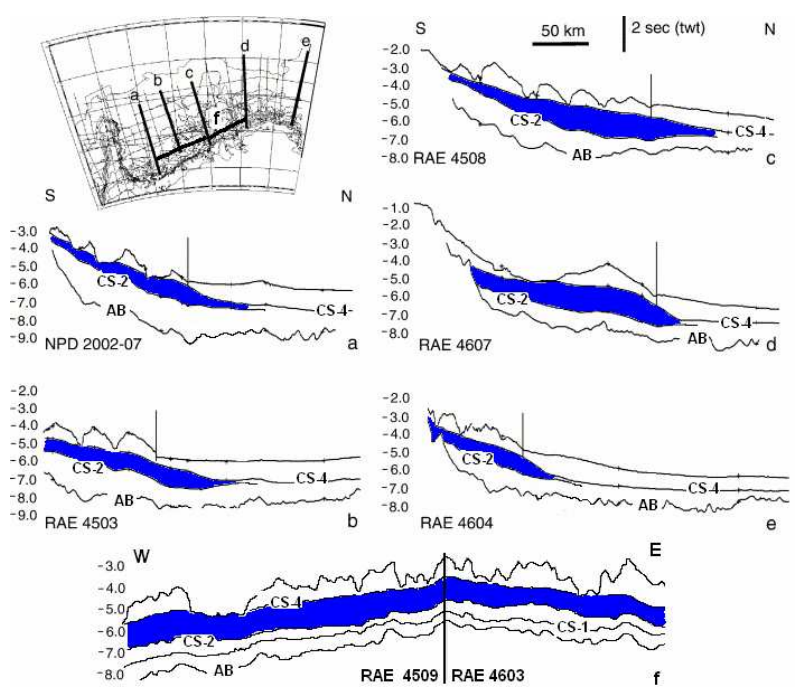

Figure 2: Selected N-S seismic profiles along the Cosmonaut Sea margin (a-e) and a composite E-W oriented seismic line (f). The blue area marks the extent of the regional wedge. Vertical line (in figures a-e) denotes the present transition between the upper and lower rise. Modified from Kuvaas et al., 2005.

\section{CS-B}

Numerous convex-up seismic units overlie the CS-1 surface on the upper rise (Fig. 3). The convex units appear to be abundant within two sectors of the continental margin, forming distinct depocentres off Lutzow-Holm Bay and off the Casey-/Amundsen Bay area (Fig. 3, left). In the distal and eastern part of the study area, the CS-B sequence displays a rather uniform thickness. The internal reflectors appear to be onlapping the flanks of the proximal depocentres.

Interpretation: The CS-B sequence comprises two depocentres positioned at the foot of the continental slope with several overlapping sediment lobes of variable size. We interpret these depocentres as deep-sea fans. The sheeted deposits, flanking the two submarine fans, may either correspond to turbidite sheets or sheeted contourite drifts (Faugeres et al.,1999; Maldonado et al., 2005).

\section{CS-C (The Cosmonaut Sea Wedge)}

The seismic sequence (CS-C) can be subdivided into a proximal part and a distal part, on the basis of its morphology (Fig. 4). In the proximal part, a wedgeshaped sediment mound forms a paleo-bulge below the upper part of the continental rise. The mound thins rapidly and appears to wedge out approximately at the transition between the upper and lower continental rise. This sediment wedge, termed the Cosmonaut Sea Wedge, can be identified on all seismic dip lines along the Cosmonaut Sea margin (Fig. 2). The outer boundary of the Cosmonaut Sea Wedge is outlined in Figure 1. The 

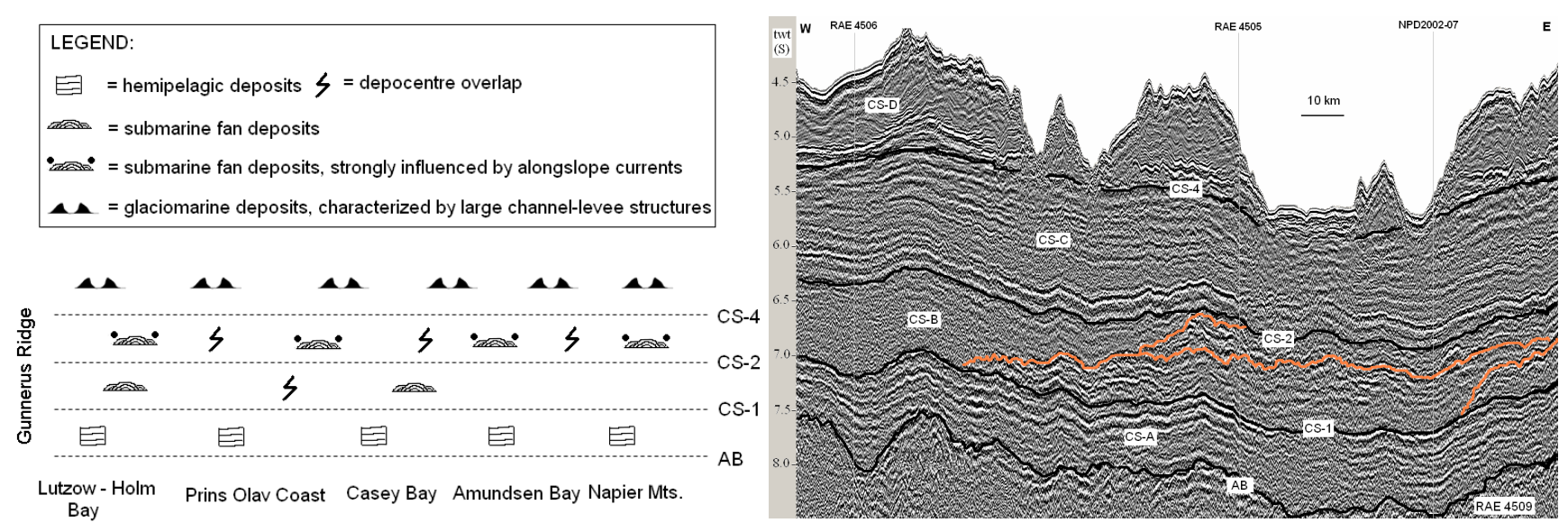

Figure 3. Left: Summary of the main stages of the depositional evolution of the Cosmonaut Sea. Right: the seismic profile RAE 4509, showing the seismic sequences. Several overlapping sediment lobes can be observed within sequence CS-B. The westernmost lobe is acoustically transparent. The (lower) central lobe reveals internal layers that downlap the unconformity CS-1 towards the west and onlap the flank of a third sediment lobe to the east. The location of the seismic profile is indicated in Figure 1.

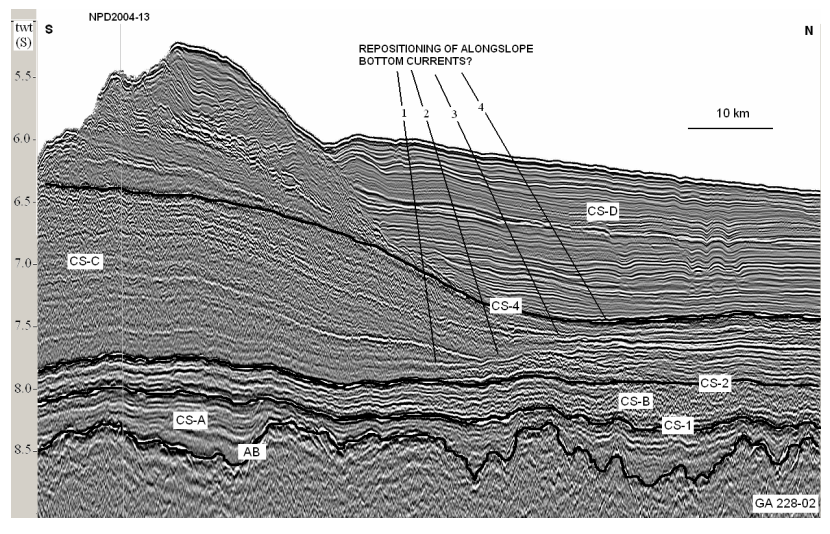

Figure 4: The seismic profile GA 228-02 indicates a progradational stacking pattern within the regional wedge. The flow axis of the alongslope currents appear to be relocated towards more distal locations in response to pulsed sediment-supply from the continental margin. The location of the seismic profile is indicated in Figure 1

boundary is markedly sinuous, thus indicating alongslope variations in the width of the wedge. The regional wedge also displays clear variations in thickness along the continental margin. This feature is best observed in the seismic profiles with a N-S orientation (Fig. 2). Erosion is locally observed along the outer boundary of the wedge, particularly in the region close to the Gunnerus Ridge.

The distal part of the sequence is generally much thinner than the proximal part. In this outer region the sequence is dominated by two main types of seismic facies; (A) a well-stratified and mounded facies and (B) a well-stratified and sheeted facies (Fig. 4).

Interpretation: The position of the Cosmonaut Sea Wedge at the foot of the continental slope, along with its wedge-shaped morphology, suggested to Kuvaas et al.,
$(2004 ; 2005)$ that it either represented a large sediment drift or a submarine fan. The elongation of the wedge (along the continental slope) together with its distinct outer boundary favoured an interpretation in terms of bottom currents. The wedge was hence classified as a slope-plastered drift, with reference to Stow et al., (2002). The lack of an extensive erosion surface at the base of the wedge suggested that it consisted of sediments that were supplied mainly during the seaward migration of the coastline (Kuvaas et al., 2004; 2005). They speculated that this material was redistributed by westward-flowing bottom currents in a similar manner as discussed for the Ceuta Drift in the Alboran Sea (Ercilla et al., 2002).

The present study indicates a more complex origin of the Cosmonaut Sea Wedge. As opposed to the Ceuta Drift, it displays clear variations in thickness along the margin (Fig. 2) and a highly sinuous outer boundary (Fig. 1). In Figure 1 we have outlined the main axis of progradation (yellow arrows) within different sectors of the Cosmonaut Sea Wedge. Based on these observations we propose that the deposits making-up the wedge are related to a multi-point supply from the adjacent margin which fed several overlapping depocentres. This concept is supported by the observation of overlapping reflector configurations in between the depocentres.

The marginal deposits at the stratigraphic level of sequence CS-C appear to be reworked by alongslope processes. We interpret the two types of seismic facies observed in the distal parts of the CS-C sequence respectively as (A) elongated mounded drifts and (B) contourite sheets. The structure and morphology of the mounded deposits (elongated alongslope, internal reflectors indicative of east to west progradation, erosional southern margin) indicate control by westward flowing bottom currents. These currents also appear to have reworked the proximal depocentres making-up the 


\section{$10^{\text {th }}$ International Symposium on Antarctic Earth Sciences}

Cosmonaut Sea Wedge. We hence propose that the fan development that was initiated during the CS-B sequence continued across the CS-2 surface with an additional component of bottom current flow. In central parts of the fans, where the progradation is strongest, the seismic profiles indicate that the flow axis of the bottom currents are repositioned towards more distal locations in response to pulsed sediment supply from the margin and in parallel in response to the relief being developed (Fig. 4). This might suggest that the interaction between alongslope and downslope processes was controlled by sea-level changes, the margin being mainly inundated by sediments during sea-level low-stands as the continental shelf was subjected to erosion. Along the flanks of the fan systems we observe aggradational reflector geometries and longer term stabilities in the position of the alongslope currents.

\section{$C S-D$}

The uppermost part of the sediment succession is previously described and analysed in detail by Kuvaas et al., (2004; 2005) and Solli et al., (2007). The CS-4 surface is considered to reflect the base of the glaciomarine deposits along the continental margin of the Cosmonaut Sea.

\section{Summary}

The Cosmonaut Sea Wedge is the result of a complex interplay between down-slope and along-slope processes. The wedge comprises several overlapping depocentres that are strongly modified by westward flowing bottom currents. The action of these currents together with sealevel changes is considered to have controlled the growth of the wedge. We interpret the Cosmonaut Sea Wedge as a composite feature consisting of several bottom current reworked fan systems.

Acknowledgements. This contribution is part of a joint research project between the University of Bergen and PMGRE/VNIIOkeangeologia in St. Petersburg. Project support was provided by the Norwegian Petroleum Directorate (NPD). We thank Morten Sand, Harald Brekke and Olvar Løvås of NPD for their support and encouragement during the project. We would also like to thank Geoscience of Australia and Howard Stagg for providing us with migrated versions of the GA-228 data. The manuscript was critically reviewed by Carlota Escutia, David Piper and Howard Stagg, whose constructive comments are much appreciated by the authors.

\section{References}

Ercilla, G., J. Baraza, B. Alonso, F. Estrada, D. Casas, and M. Farran (2002), The Ceuta Drift, Alboran Sea, southwestern Mediterranean, in Deep-Water Contourite Systems: Modern Drifts and Ancient Series, Seismic and Sedimentary Characteristics, edited by D. A. V. Stow, J. A. Howe, J. C. Faugeres, A. R. Viana, Mem. Geol. Soc. London, 22, 155-170.

Faugeres, J. C., D. A. V. Stow, P. Imbert, and A. Viana (1999), Seismic features diagnostic of contourite drifts, Mar. Geol. 162, 1-38.

Kuvaas, B., Y. K. Kristoffersen, J. Guseva, G. Leitchenkov, V. Gandjukhin, O. Løvås, M. Sand, and H. Brekke (2004), Input of glaciomarine sediments along the East Antarctic continental margin: depositional processes on the Cosmonaut Sea continental slope and rise and a regional acoustic stratigraphic correlation from $40^{\circ} \mathrm{W}$ to $80^{\circ} \mathrm{E}$, Mar. Geophys. Res., 25, 247-263.

Kuvaas, B., Y. K. Kristoffersen, J. Guseva, G. Leitchenkov, O. Løvås, M. Sand, and H. Brekke, (2005), Interplay of turbidite and contourite deposition along the Cosmonaut Sea/Enderby Land margin, East Antarctica, Mar. Geol., 217, 143-159.

Leitchenkov, G. L., Y. B. Guseva, and V. V. Gandyukhin, (2007), Cenozoic environmental changes along the East Antarctic margin inferred from regional seismic stratigraphy, this volume.

Maldonado, A., A. Barnolas, F. Bohoyo, C. Escutia, J. GalindoZaldivar, F. J. Hernandez-Molina, A. Jabaloy, F. J. Lobo, C. H. Nelson, J. Rodriguez-Fernandez, L. Somoza, and J. T. Vazquez, (2005), Miocene to recent contourite drifts development in the northern Weddell Sea (Antarctica), Global Planet Change, 45, 99129.

Solli, K., B. Kuvaas, Y. K. Kristoffersen, G. Leitchenkov, J. Guseva, V. Gandyukhin, (2007), Seismic morphology and distribution of inferred glaciomarine deposits along the East Antarctic continental margin, $20^{\circ} \mathrm{E}-60^{\circ} \mathrm{E}$, Marine Geology, 237 (3-4), 207-223.

Stow, D. A. V., J. C. Faugeres, J. A. Howe, C. J. Pudsey, and A.R. Viana (2002), Bottom currents, contourites and deep-sea sediment drifts: current state-of-the-art, in Deep-Water Contourite Systems : Modern Drifts and Ancient Series, Seismic and Simentary Characteristics, edited by D. A. V Stow, J. A. Howe, J. C. Faugeres, A.R. Viana, Mem. Geol. Soc. London, 22, 7-20. 